Orbicular wanting. Fringes concolorous. Hind wings pale yellowish white, sub-pellucid. Beneath with distinct discal black spot visible above; a dark waved exterior line and indications on costa of a sub-terminal line; costal region shaded with fuscous. Fore wings dark with a waved perpendicular exterior line and a sub-obsolete sub-terminal line.

Expanse 26 m. m. Hab. Texas. M. von. Meske, No. 2,611.

Graphiphora rubrica, n. 8 .

․ Thorax yellowish fuscous or gray. Collar marked by a faint black line. Superior wings of a yellow'sh gray, suffused sometimes with a ruddy brown tinge; a black dash at base of fore wings. T. a. line geminate, waved; outer line biack, more prominent on inferior border. T. p. line geminate, faintly black, commencing on costa above the reniform, boldly exserted and passing to the inferior border of wing directly in a line with the internal border of the reniform and terminating in a black dash. Sub-terminal commeneing with a yellowish white apical patch and continuing as a clearly cut even yellow line to the inferior angle; orbicular spot oval, concolorous, light annulus, ablique; reniform concolorous with a black spot in the lower portion, light ringed, with inner margin most expressed. Costal margin with black and white markings; fringes concolorous with sub-terminal line; inferior portion of wings neariy concolorous with thorax. Inferior wings whitish, discal spot and arcuated line black; terminal line a series of black dashes; beneath same lines, only more marked.

Expanse 32 m. m. Hab. Rafael, Cal., April, No. 4, M. v. Osten Sacken.

The distinctive character of this species is the pale even sub-terminal line arising from a pale apical patch.

\title{
CORRESPONDENCE.
}

EGG-FEEDING MITES.

DEAR SIR,- -

In the February number (p. 22) you quote Dr. Hagen as saying that "in the whole European literature $I$ have not been able to find anything 
about Acari eating eggs, so the fact seems new and is very important." The Dermaleichus figured in my 5th Mo. Rep. (p. 87) feeds upon the eggs of Mytilaspis pomicorticis, as well as upon the insect proper under the scale. In fact I find it more often feeding on the eggs. Dr. Packard long since observed and figured a mite (Nothrus ovivorus) that preys on the eggs of the Fall Canker-worm (Anisopteryx pometaria Harr.); while the beneficia effects of the Locust Mite (Trombidium locustarum) in destroying the eggs of the Rocky Mountain Locust have been frequently referred to of late years in my Reports, and recently in the February number of the American Naturalist.

St. Louis, Mo., March 8, 1878.

\section{V. RILEY.}

\section{ARCTIA ANTHOLEA Boisd.}

DEAR Sir,-

Assuming that the figure of this species given in Stretch's Zygaenidæ and Bombyc:dæ, plate 3 , fig. 8 , is correct, and $I$ have no doubt of it, then this species is identical with the European species, Euprepia judica Esp., and as this name has priority, antholea falls.

W. V. Andrews, Brooklyn, N.Y.

Dear Sir,-

CATOCALA MARMORATA.

Three good specimens of Catocala marmorata were collected by me at sugaring the latter part of August last, and also one fine specimen of relicta.

Rye, Westchester Co., N.Y., Jan'y 29, 1878.

\section{S. H. VAN WAGENEN.}

\section{SAMIA COLUMBIA.}

DEAR SIR,-

From cocoons of columbia kindly sent me by Mr. Anson Allen, of Orono, Maine, "found on larch trees many feet from the ground, where 
they would be exposed to all the changes of winter weather," a sing'e male escaped in the warm room where I kept the crysalids. I found the specimen February 14th, but it had broken its wings, and I have no doubt it escaped one or two days previously. I had no immediate expectation of the chrysalids hatching, and hence did not examine the cocoons daily. I think it worthy of record that this species has the peculiar smell characteristic of cecropia.

A. R. Grote, Buffa'o, N.Y.

DEAR SIR,-

I would like to refer to a statement of a correspondent (in July No. of ENTomcLoGisT) regarding the appearance in large numbers, in the vicinity of this city, of Melitaea phaeton. Although collecting nearly every day during the summer, I did not observe a single specimen of this butterisy, nor have I seen one collected by any one else. M. tharos is one of our most common butterflies; perhaps this was he one intended.

W. H. Harrington, Ottawa, Ont.

DEAR SIR,--

In the summer of 1876 , while examining the paper bands placed in our orchard to entrap the larva of the Coding Moth (Carpocapsa pomonella Linn.), I found quite a number of their larvæ and chrysalids apparently eaten by some cannibal, which, after close watch, proved to be Tenebrioides laticollis Horn. On several occasions I found them half way into a fresh chrysalis of C. pomonella.

This beetle, as well as $T$. castanea Mels., is very common here, and I will try to encourage this useful tas e of theirs.

Charles D. Zimmerman, Buffalo, N.Y.

DEAR SIR,-

Four specimens of Papilio cresphontes were captured in Fairfield Co., Conn., last summer, about the 25th of July. Others were seen.

New York, March 10th, 1878.

Geo. W. PECK. 